\title{
Simvastatin protects human osteosarcoma cells from oxidative stress-induced apoptosis through mitochondrial-mediated signaling
}

\author{
XIAO-HONG ZHAO ${ }^{1}$, ZHE-RONG XU ${ }^{1}$, QIN ZHANG $^{1}$ and YUN-MEI YANG ${ }^{2}$ \\ ${ }^{1}$ Department of Geriatrics; ${ }^{2}$ State Key Laboratory for Diagnosis and Treatment of Infectious Diseases, \\ First Affiliated Hospital, School of Medicine, Zhejiang University, Hangzhou, Zhejiang 310003, P.R. China
}

Received July 22, 2011; Accepted October 10, 2011

DOI: $10.3892 / \mathrm{mmr} .2011 .641$

\begin{abstract}
Apoptosis of osteoblasts has been proposed as the common basis of osteoporosis, with oxidative stress as the major cause. This study was performed to investigate the protective effect of simvastatin $(0.001-0.1 \mu \mathrm{M})$ on $100 \mu \mathrm{M}$ hydrogen peroxide $\left(\mathrm{H}_{2} \mathrm{O}_{2}\right)$-mediated oxidative stress-induced apoptosis in human osteosarcoma (MG63) cells and the molecular mechanisms involved. Cell apoptosis was evaluated by observation of morphological changes and Annexin V-propidium iodide double staining followed by flow cytometric analysis. MTS assays were used to evaluate cell viability. To investigate the underlying molecular mechanisms, the expression of caspase-3, caspase- 9 and Bcl-2 were analyzed by Western blotting. Following stimulation with $\mathrm{H}_{2} \mathrm{O}_{2}$ for $24 \mathrm{~h}$, a high proportion of MG63 cells underwent apoptosis, while a dosedependent inhibition of apoptosis was observed in the presence of simvastatin. A significant, dose-dependent reduction in the expression of caspase- 3 and caspase- 9 protein induced by $\mathrm{H}_{2} \mathrm{O}_{2}$ in MG63 cells was observed in response to simvastatin and the Bcl-2 levels were increased. In conclusion, simvastatin protects MG63 cells from oxidative stress-induced apoptosis through downregulation of caspase- 3 and caspase-9 activation and upregulation of Bcl-2 expression, suggesting a protective effect in osteoporosis.
\end{abstract}

\section{Introduction}

Osteoporosis has been defined as a systemic skeletal disease characterized by gradual loss and microarchitectural deterioration of bone tissue, resulting in increased bone fragility

Correspondence to: Dr Yun-Mei Yang, State Key Laboratory for Diagnosis and Treatment of Infectious Diseases, First Affiliated Hospital, School of Medicine, Zhejiang University, 79 Qingchun Road, Hangzhou, Zhejiang 310003, P.R. China

E-mail: yangyunmei2003@163.com

Key words: simvastatin, oxidative stress, human osteosarcoma cells, apoptosis and susceptibility to fracture (1). Osteoblasts are responsible for bone formation while osteoclasts are involved in bone resorption. Conditions such as postmenopausal osteoporosis are associated with significant changes in bone turnover; bone formation decreases and bone resorption increases or remains the same, resulting in net bone loss $(2,3)$.

Oxidative stress, resulting from excessive levels of reactive oxygen species (ROS), represents a major cause of cellular damage and death in a plethora of pathological conditions, including osteoporosis. This is associated with distinct increases in blood levels of oxidative stress markers (4-6). The main oxygen species responsible for oxidative stress are hydrogen peroxide $\left(\mathrm{H}_{2} \mathrm{O}_{2}\right)$, the free radical superoxide anion $\left(\mathrm{O}_{2}^{-}\right)$and the hydroxyl radical $\left(\mathrm{OH}^{-}\right)$. Osteoblasts produce antioxidants such as glutathione peroxidase that protect against ROS (7) and osteoclast-generated superoxide contributes to bone degradation (8). In ovariectomized rats, a model of postmenopausal osteoporosis, increased levels of lipid peroxidation and $\mathrm{H}_{2} \mathrm{O}_{2}$ and decreased levels of enzymatic antioxidants were detected in tissue homogenates from the femora (9). Furthermore, antioxidant enzyme GPX1 gene polymorphisms are associated with low bone mineral density (BMD) and increased bone turnover markers (10).

The 3-hydroxy-3-methylglutaryl-coenzyme A (HMG-COA) reductase inhibitor, simvastatin, is a widely used cholesterollowering drug that inhibits hepatic cholesterol biosynthesis. Recent studies have shown the beneficial effects of statins on BMD $(11,12)$. It has been suggested that a number of statin drugs, including simvastatin, increase the mRNA expression of bone morphogenetic protein 2 (BMP-2) in osteoblasts and are involved in promoting osteoblast differentiation with a subsequent increase in bone formation, when injected subcutaneously over the murine calvaria (13). Numerous animal and human studies have been performed to elucidate the clinical importance of statins. The majority of experimental and epidemi ological studies have shown statins to have beneficial effects on bone metabolism, as evaluated by BMD (14-16) and fracture risk (17-19). Statins have therefore been proposed as potential agents in the treatment of osteoporosis.

The MG63 human osteogenic sarcoma cell line is widely studied as a typical example of human osteoblast-like cells $(20,21)$. This study aimed to evaluate the effects of simv- 
astatin on MG63 cell death in response to oxidative stress by investigation of Bcl-2 and caspase-9 expression and caspase-3 activity.

\section{Materials and methods}

Reagents and antibodies. $\mathrm{H}_{2} \mathrm{O}_{2}$ was purchased from Sigma (St. Louis, MO, USA) and prepared immediately prior to use in phosphate-buffered saline (PBS) at $100 \mu \mathrm{M}$. A stock solution of simvastatin (Zhejiang Xinchang Pharmaceutical Co., Ltd.) dissolved in dimethyl sulfoxide (DMSO) at $10 \mathrm{U} /$ $\mathrm{ml}$ was prepared and stored at $-30^{\circ} \mathrm{C}$. Working solutions of simvastatin $(0.1,0.01$ and $0.001 \mu \mathrm{M})$ were prepared from the stock. The 3-(4,5-dimethylthiazol-2-yl)-5-(3-carboxym ethoxyphenyl)-2-(4-sulfophenyl)-2H-tetrazolium, inner salt (MTS) was purchased from Promega (San Luis Obispo, CA, USA). Annexin V/FITC kits were purchased from Bender MedSystems GmbH (Vienna, Austria). Antibodies used for Western blot analysis were rabbit anti-active caspase-3 and caspase-9 polyclonal antibodies (Chemicon, Temecula, CA, USA) recognizing only the cleaved large subunit (17 kDa, caspase-3; $37 \mathrm{kDa}$, caspase-9), and rabbit anti-Bcl-2 polyclonal antibodies were purchased from Cell Signaling Technologies (Beverly, MA, USA). Anti-actin was purchased from Santa Cruz Biotechnology (Santa Cruz, CA, USA). Caspase-3 and caspase-9 colorimetric activity assay kits and recombinant active caspase-3, and caspase- 9 standards were purchased from Chemicon.

Cell culture and treatment. The osteosarcoma cell line, MG63 cell, was obtained from the State Key Laboratory for Diagnosis and Treatment of Infectious Diseases, Zhejiang University, China. MG63 cells were cultured in Dulbecco's modified Eagle's medium (DMEM) supplemented with $10 \%$ fetal bovine serum (FBS), $100 \mathrm{U} / \mathrm{ml}$ penicillin and $100 \mu \mathrm{g} / \mathrm{ml}$ streptomycin, in a humidified $5 \% \mathrm{CO}_{2}$ atmosphere at $37^{\circ} \mathrm{C}$. The cells were passaged every 3 days. MG63 cells were seeded at a density of $2 \times 10^{6}$ cells/dish in $100-\mathrm{mm}$ dishes in DMEM with $2 \%$ calf serum. Confluent cell cultures were incubated in the presence or absence of simvastatin $(0,0.001,0.01$ and $0.1 \mu \mathrm{M}$ ) for $2 \mathrm{~h}$ followed by stimulation with $100 \mu \mathrm{M} \mathrm{H}_{2} \mathrm{O}_{2}$ and further incubation for $24 \mathrm{~h}$. MG63 cells were observed for morphological changes.

Flow cytometric analysis. Recovery of cells was monitored by examination of the levels of apoptosis $24 \mathrm{~h}$ following $\mathrm{H}_{2} \mathrm{O}_{2}$ treatment. Annexin $\mathrm{V}$ binding and propidium iodine (PI) staining were determined by flow cytometry. Cells were treated with $100 \mu \mathrm{M} \mathrm{H}_{2} \mathrm{O}_{2}$ for $24 \mathrm{~h}$, washed with ice-cold PBS and double-stained with FITC-conjugated Annexin V protein and PI for $20 \mathrm{~min}$. Flow cytometry was performed with a 488-nm laser coupled to a cell sorter (FacsCalibur; BD Biosciences, San Jose, CA, USA). Cells stained with PI and Annexin $\mathrm{V}$ were considered necrotic, while cells stained only with Annexin V were considered apoptotic.

MTS assay. MG63 cells (5,000 cells/well) were seeded in 96-well microtiter plates. Following incubation with 0.001 , 0.01 and $0.1 \mu \mathrm{M}$ simvastatin for $2 \mathrm{~h}$, cells were treated with $100 \mu \mathrm{M} \mathrm{H}_{2} \mathrm{O}_{2}$ for a further $24 \mathrm{~h}$. Subsequently, $20 \mu \mathrm{l}$ MTS
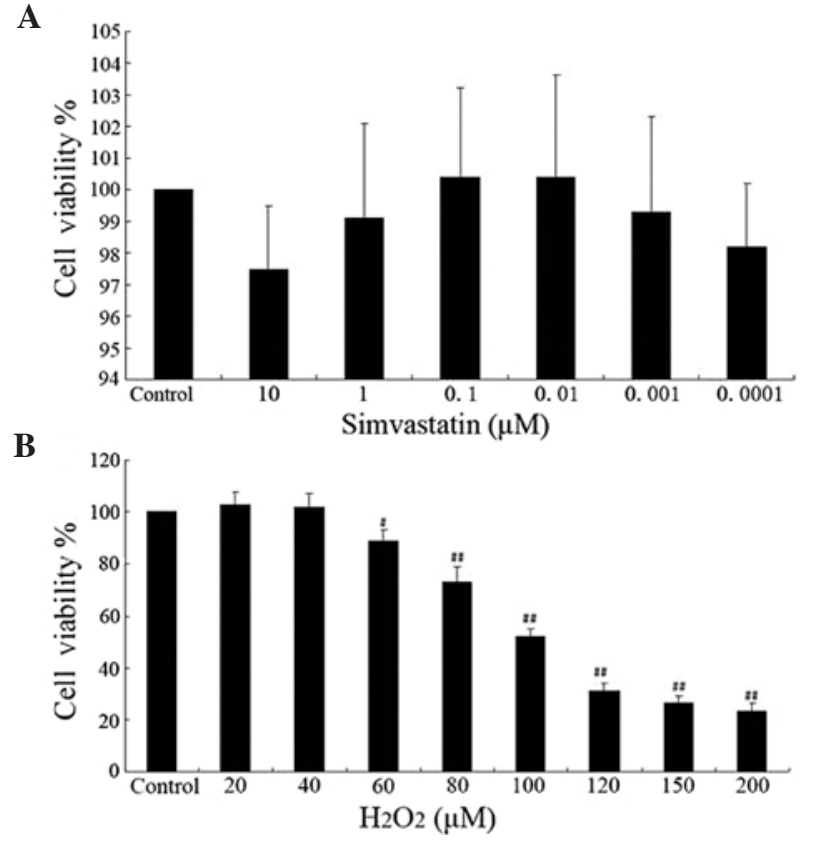

Figure 1. Determination of experimental conditions. MG63 cells were cultured with various concentrations of (A) simvastatin or (B) $\mathrm{H}_{2} \mathrm{O}_{2}$ for $24 \mathrm{~h}$ and cell viability was assessed by MTS assay. ${ }^{\#} \mathrm{p}<0.05$ compared with control group, ${ }^{\# \#} \mathrm{p}<0.01$ compared with control group.

solution was added to each well, and the plates were incubated for $3 \mathrm{~h}$ at $37^{\circ} \mathrm{C}$. The absorbance was measured at $490 \mathrm{~nm}$ and used to calculate the relative ratio of cell viability.

Western blot analysis. Protein expression of activated caspase-3, caspase-9 and Bcl-2 was analyzed by Western blotting. Cytoplasmic extracts were prepared in lysis buffer containing $150 \mathrm{mM} \mathrm{NaCl}, 10 \mathrm{mM}$ Tris- $\mathrm{HCl}(\mathrm{pH} 7.9), 0.5 \%$ Triton X-100, 0.6\% NP-40, and protease inhibitors, $1 \mathrm{mg} / \mathrm{ml}$ leupeptin, $1 \mathrm{mg} / \mathrm{ml}$ pepstatin A and $2 \mathrm{mg} / \mathrm{ml}$ aprotinin. Protein content was determined using a detergent compatible (DC) protein assay kit (Bio-Rad, Richmond, CA, USA). Protein (40 $\mu \mathrm{g}$ mixed with $2 \mathrm{X}$ SDS sample buffer) was separated by $10 \%$ polyacrylamide gel electrophoresis and transferred to a nitrocellulose membrane (Bio-Rad, Hercules, CA, USA) prior to incubation for $2 \mathrm{~h}$ in blocking buffer (PBS with $7.5 \%$ non-fat dry milk, $2 \%$ BSA, $0.1 \%$ Tween). Active caspase-3, caspase-9 and $\mathrm{Bcl}-2$ proteins were detected by incubation with appropriate primary antibodies (1:400 in blocking buffer) overnight at $4^{\circ} \mathrm{C}$. Subsequently, membranes were washed (PBS with $0.1 \%$ Tween-20) and incubated with peroxidase-conjugated goat anti-rabbit $\operatorname{IgG}$ (Pierce, 1:10000 dilution in blocking buffer) for $1 \mathrm{~h}$ at room temperature. Membranes were then washed in PBS and developed using the enhanced chemiluminescence (ECL) detection system (Amersham Biosciences, Uppsala, Sweden).

Statistical analysis. All experiments were performed on three or more occasions and results are expressed as the mean \pm SD. Statistical significance was analyzed by one-way analysis of variance (ANOVA) and $p<0.05$ was considered to be statistically significant. 

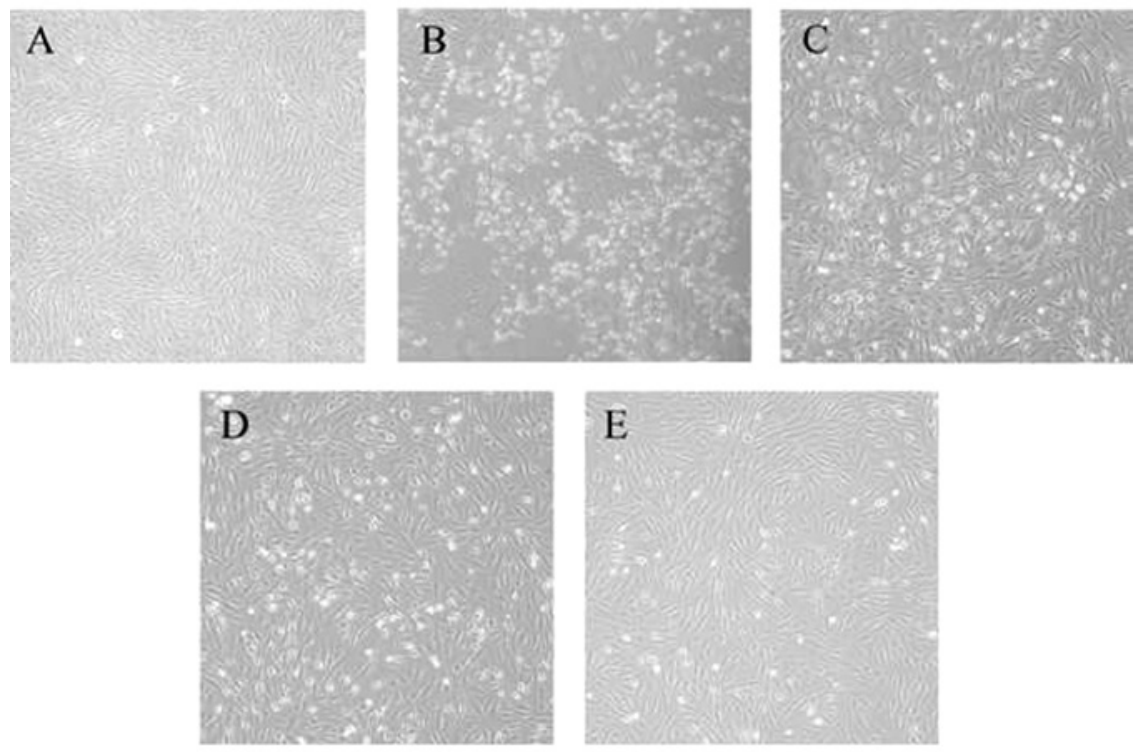

Figure 2. Simvastatin inhibited morphological changes of MG63 cells induced by $\mathrm{H}_{2} \mathrm{O}_{2}$. When treated with $\mathrm{H}_{2} \mathrm{O}_{2}(100 \mu \mathrm{M})$ for 24 h, a large proportion of cells exhibited signs of apoptosis such as detachment and cytoplasmic condensation leading to rounding. (A) MG63 cells without $\mathrm{H}_{2} \mathrm{O}_{2}$ or simvastatin treat-

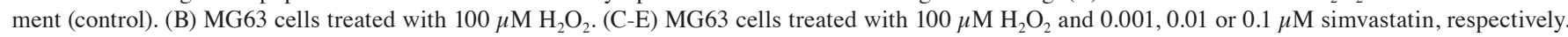
(magnification, $\mathrm{x} 10)$.

\section{Results}

Selection of conditions for simvastatin and $\mathrm{H}_{2} \mathrm{O}_{2}$ treatment. MG63 cells were cultured in DMEM supplemented with simvastatin $(0.0001,0.001,0.01,0.1,1$ or $10 \mu \mathrm{M})$ for $24 \mathrm{~h}$. No detrimental effects on cells were observed (Fig. 1A). Three concentrations of simvastatin were selected $(0.001,0.01$ and $0.1 \mu \mathrm{M}$ ) for further investigation based on these observations. The working concentration of $\mathrm{H}_{2} \mathrm{O}_{2}$ was determined in a series of dose-response MTS assays of viability. Treatment with increasing concentrations of $\mathrm{H}_{2} \mathrm{O}_{2}$ for $24 \mathrm{~h}$ caused a dose-dependent loss of cell viability (Fig. 1B). Treatment with $100 \mu \mathrm{M} \mathrm{H}_{2} \mathrm{O}_{2}$ reduced cell viability (survival rate, $52.2 \pm 3.0 \%$ ). This concentration was used in subsequent experiments for the investigation of the effects of simvastatin on apoptosis.

Morphological changes of MG63 cells. Morphological changes in MG63 cells treated with $\mathrm{H}_{2} \mathrm{O}_{2}(100 \mu \mathrm{M})$ were observed in the presence or absence of simvastatin $(0.001,0.01$ and $0.1 \mu \mathrm{mol} / 1)$. Following $\mathrm{H}_{2} \mathrm{O}_{2}$ treatment, a high proportion of cells exhibited apoptosis-like morphological changes, such as detachment, and cytoplasmic condensation leading to rounding. However, the proportion of cells with abnormal morphology suggestive of apoptosis decreased with increasing simvastatin concentration (Fig. 2).

Simvastatin blocked MG63 cell apoptosis induced by $\mathrm{H}_{2} \mathrm{O}_{2}$. The effects of simvastatin on $\mathrm{H}_{2} \mathrm{O}_{2}$-induced cell apoptosis were quantified by flow cytometric analysis, and the percentage of apoptotic cells detected by Annexin V-FITC and PI double staining. Cell viability was determined by MTS assay. Significantly increased apoptosis was observed in MG63 cells treated with $100 \mu \mathrm{M} \mathrm{H}_{2} \mathrm{O}_{2}$ compared with the control $(27.77 \pm 2.31$ vs. $1.9 \pm 0.98 \%, \mathrm{p}<0.01)$. The percentages of apoptotic cells treated with $\mathrm{H}_{2} \mathrm{O}_{2}$ and simvastatin at 0.001 ,
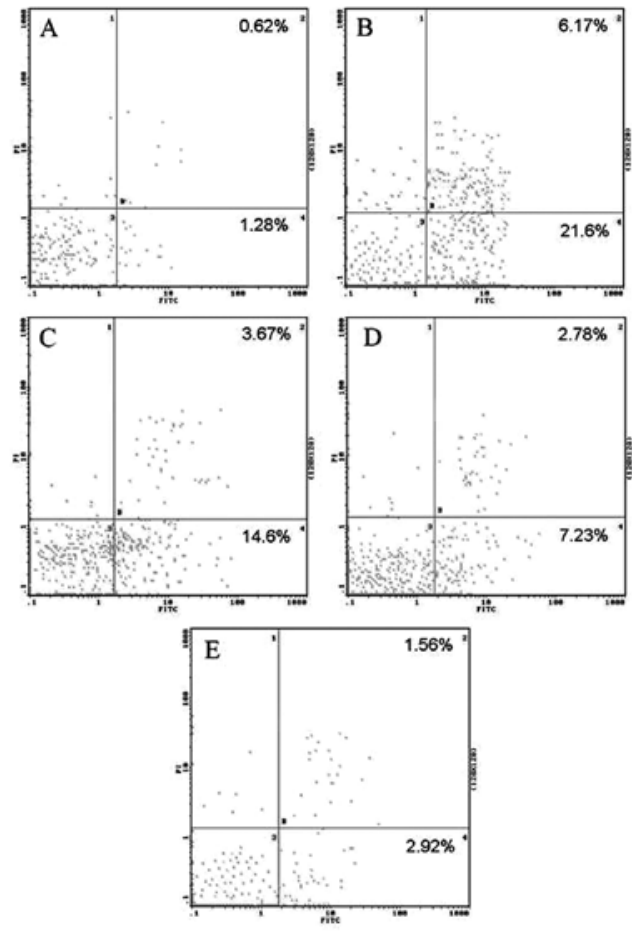

Figure 3. Simvastatin blocked $\mathrm{H}_{2} \mathrm{O}_{2}$-induced apoptosis in MG63 cells Apoptotic cells were detected by Annexin V and propidium iodine double staining. (A) Untreated MG63 cells (control). (B) MG63 cells treated with $100 \mu \mathrm{M} \mathrm{H}_{2} \mathrm{O}_{2}$. (C-E) MG63 cells treated with $100 \mu \mathrm{M} \mathrm{H}_{2} \mathrm{O}_{2}$ and $0.001,0.01$ or $0.1 \mu \mathrm{M}$ simvastatin, respectively.

0.01 or $0.1 \mu \mathrm{M}$ were $18.27 \pm 1.72,10.01 \pm 2.11$ and $4.48 \pm 1.55 \%$, respectively. Simvastatin significantly reduced the percentage of apoptotic cells in a dose-dependent manner compared with the $\mathrm{H}_{2} \mathrm{O}_{2}$-treated cells (Fig. 3). Significantly decreased viability was observed by MTS assay in MG63 cells treated 


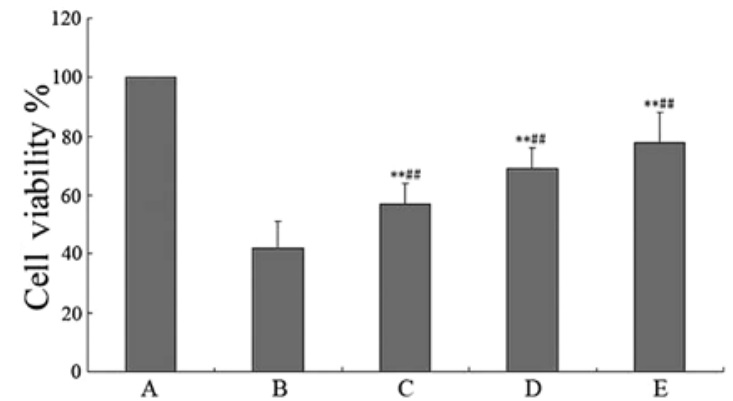

Figure 4. Simvastatin blocked apoptosis of MG63 cells induced by $\mathrm{H}_{2} \mathrm{O}_{2}$. Cell viability was evaluated by MTS assay. Simvastatin significantly increased cell viability compared with $\mathrm{H}_{2} \mathrm{O}_{2}$-treated cells in a dose-dependent manner ( $\mathrm{p}<0.01$ at all three concentrations). (A) Untreated MG63 cells (control). (B) MG63 cells treated with $100 \mu \mathrm{M} \mathrm{H}_{2} \mathrm{O}_{2}$. (C-E) MG63 cells treated with $100 \mu \mathrm{M} \mathrm{H}_{2} \mathrm{O}_{2}$ and $0.001,0.01$ or $0.1 \mu \mathrm{M}$ simvastatin, respectively; ${ }^{* *} \mathrm{p}<0.01$ compared with $\mathrm{H}_{2} \mathrm{O}_{2}$ alone; ${ }^{\# \#} \mathrm{p}<0.01$ compared with the control.

with $100 \mu \mathrm{M} \mathrm{H}_{2} \mathrm{O}_{2}$ compared with the control (42.3 \pm 9.1 vs. $99.5 \pm 2.3 \%, \mathrm{p}<0.01)$. The percentages of viable cells following treatment with $\mathrm{H}_{2} \mathrm{O}_{2}$ and simvastatin at $0.001,0.01$ or $0.1 \mu \mathrm{M}$ were $57.2 \pm 6.9,69.4 \pm 7.0$ and $78.7 \pm 10.4 \%$, respectively. Simvastatin significantly increased the percentage of cell viability in a dose-dependent manner compared with the $\mathrm{H}_{2} \mathrm{O}_{2}$-treated cells ( $\mathrm{p}<0.01$ at all three concentrations) (Fig. 4).

Simvastatin prevented $\mathrm{H}_{2} \mathrm{O}_{2}$-induced downregulation of $\mathrm{Bcl}-2$ and upregulation of caspase-3 and caspase-9 activation. The mechanism underlying the observed protective effects of simvastatin on MG63 cells against $\mathrm{H}_{2} \mathrm{O}_{2}$-induced apoptosis was investigated by analysis of the cleaved form of caspase-3 (17 kDa), caspase-9 $(37 \mathrm{kDa})$ and $\mathrm{Bcl}-2(28 \mathrm{kDa})$ by Western blot analysis. Simvastatin at concentrations $>0.001 \mu \mathrm{M}$ significantly upregulated the protein expression of caspase- 3 and caspase-9 in MG63 cells following $24 \mathrm{~h}$ of $\mathrm{H}_{2} \mathrm{O}_{2}$ treatment and prevented $\mathrm{H}_{2} \mathrm{O}_{2}$-induced downregulation of $\mathrm{Bcl}-2$. A direct correlation was observed between the magnitude of this effect and the concentration of simvastatin (Fig. 5).

\section{Discussion}

ROS are free radical-containing molecules derived from oxygen and its products. Recent studies have reported increased ROS as a significant factor in the occurrence of senile, postmenopausal and other types of primary osteoporosis $(6,22)$. A negative correlation has been reported between the level of oxidative stress and bone density in the elderly (6). Related data showed that ROS promoted activation of osteoclast and bone resorption (23), and inhibited proliferation and differentiation of osteoblasts (24). In this study a dose-dependent reduction in viability was detected by MTS assay in cells treated with increasing concentrations of $\mathrm{H}_{2} \mathrm{O}_{2}$ for $24 \mathrm{~h}$. Based on these observations cells were treated with $100 \mu \mathrm{M} \mathrm{H}_{2} \mathrm{O}_{2}$ in subsequent experiments.

Statins are 3-hydroxy-3-methylglutaryl-coenzyme A (HMG-COA) reductase inhibitors, widely used in the clinic for regulation of cholesterol levels in the blood. In recent years, statins have been shown to stimulate osteoblast proliferation in vitro, and to promote new bone formation in the skull and os
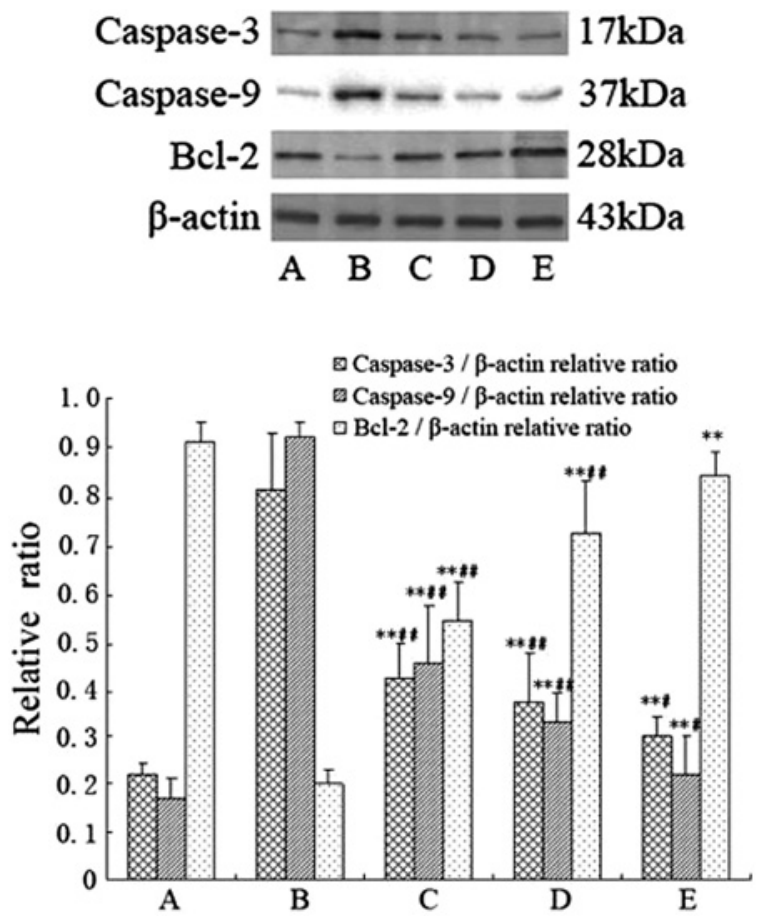

Figure 5. Effect of simvastatin on the expression of proteins in $\mathrm{H}_{2} \mathrm{O}_{2}$-treated MG63 cells. The expression of caspase-3, active caspase- 9 and Bcl-2 in treated MG63 cells was analyzed by Western blot analysis. Top panel: Ratio of the band of interest and the $\beta$-actin or $\alpha$-tubulin band. Bottom panel: (A) Untreated MG63 cells (control). (B) MG63 cells treated with $100 \mu \mathrm{M}$ $\mathrm{H}_{2} \mathrm{O}_{2}$. (C-E) MG63 cells treated with $100 \mu \mathrm{M} \mathrm{H}_{2} \mathrm{O}_{2}$ and $0.001,0.01$ or $0.1 \mu \mathrm{M}$ simvastatin, respectively; ${ }^{* *} \mathrm{p}<0.01$ compared with $\mathrm{H}_{2} \mathrm{O}_{2}$ treatment alone, ${ }^{\#} \mathrm{p}<0.01$ compared with control.

integumentale of newborn rats (13). Statins stimulate increased expression of the BMP-2 gene in osteoblasts, and simvastatin has been suggested to activate the protein kinase pathway and resist the inhibitory action of TNF- $\alpha$ on BMP-2-induced osteoblast differentiation by regulating Smad signaling and Ras/Rho mitosis $(25,26)$. Statins are associated with a variety of other activities including induction of osteoblast differentiation (27), resistance of the inhibitory effects on osteoblast growth and enhancement of osteoclast activity induced by IL-1, IL-6, TNF- $\alpha$ and other inflammatory factors (28), inhibition of matrix metalloproteinase activity (29), upregulation of vascular endothelial growth factor (VEGF) (30), enhanced activity of endothelial nitric oxide synthase (eNOS) (31) and inhibition of differentiation of adipose cells from multipotential stem cells (32).

In this study, no significant differences in the growth and cytotoxicity of MG63 cells in the simvastatin-treated groups (0.001, 0.01, $0.1,1$, and $10 \mu \mathrm{M}$ ) were observed compared to those of the control group. Simvastatin doses of 0.001, 0.01, and $0.1 \mu \mathrm{M}$ were chosen as the experimental model conditions, which was in accordance with the conventional $\mathrm{C}_{\max }$ dose (ng/ $\mathrm{ml}$ ) used in the clinic. Observation of cell morphology and viability revealed that the proportion of apoptotic cells induced by $\mathrm{H}_{2} \mathrm{O}_{2}$ decreased with increasing simvastatin concentration. Similarly, flow cytometric data confirmed simvastatin-associated inhibition of MG63 cells apoptosis induced by $\mathrm{H}_{2} \mathrm{O}_{2}$. It may be speculated that these protective effects contribute to the antioxidant activity of this drug. 
Apoptosis progresses via a series of complex procedures regulated by caspases, which are a group of proteases known as apoptosis effectors (33). Caspases are activated by three main activation pathways: the mitochondrial (34), death receptor (35) and endoplasmic reticulum pathways (36). Activation of caspase- 9 , the most upstream protease in the mitochondrial pathway is particularly significant in activation of the whole endogenous apoptosis pathway. Following release from mitochondria, cytochrome c combines and activates apoptotic protease activating factor 1 (Apaf-1) in a deoxyadenosine triphosphate (dATP)-dependent process. Activated Apaf- 1 combines with and activates caspase- 9 proenzyme, which cleaves the caspase- 3 proenzyme to produce the activated caspase-3 tetramer (37), which is the most critical effect protease (38).

Bcl-2 functions as a key regulator of apoptosis by modulation of mitochondrial function (39). ROS increase mitochondrial permeability, resulting in cytochrome c release. $\mathrm{Bcl}-2$ family member proteins regulate the release of mitochondrial cytochrome $\mathrm{c}$ during oxidative stress in MG63. Cell survival is enhanced when Bcl-2 expression is relatively high. Caspases are downstream of the Bcl-2 family in the apoptotic cascade. Pro-caspase- 3 is cleaved by active caspase- 9 to active caspase- 3 , which along with caspases- 6 and -7 are 'executioner' caspases, which activate a DNase responsible for the fragmentation of oligonucleosomal DNA. In this study simvastatin was shown to upregulate $\mathrm{H}_{2} \mathrm{O}_{2}$-induced expression of Bcl-2 with concomitant downregulation of active caspase- 9 expression and delayed reduction in caspase- 3 activation. These results indicated that the anti-apoptotic effect of simvastatin was due to mitigated $\mathrm{H}_{2} \mathrm{O}_{2}$ stress-induced mitochondrial dysfunction.

In conclusion, this study demonstrated that simvastatin rescues MG63 cells from $\mathrm{H}_{2} \mathrm{O}_{2}$-induced cell death, and that this protective effect is related to its antioxidant effects. Notably, the mechanism by which simvastatin prevents apoptosis appears to involve downregulation of $\mathrm{H}_{2} \mathrm{O}_{2}$-induced caspase-3 and caspase- 9 activation and upregulation of $\mathrm{Bcl}-2$ expression. These in vitro data suggest that simvastatin protects MG63 cells against $\mathrm{H}_{2} \mathrm{O}_{2}$-induced apoptosis by preventing activation of the mitochondrial pathway, thus suggesting that simvastatin may have a significant role in preventing oxidant-induced osteoporosis. However, further investigation is required to determine the upstream molecular mechanisms as well as the in vivo relevance of these observations.

\section{Acknowledgements}

This study was supported by a grant from the Health Bureau of Zhejiang Province, China (no. 2010KYB037).

\section{References}

1. Wactawski-Wende J: Periodontal diseases and osteoporosis: Association and mechanisms. Ann Periodontol 6: 197-208, 2001.

2. Isomura H, Fujie K, Shibata K, et al: Bone metabolism and oxidative stress in postmenopausal rats with iron overload. Toxicology 197: 93-100, 2004

3. Arslan H, Yalin S, Erdogan C, Bagis S and Aksit SC : Effect of free radicals and antioxidants on postmenopausal osteoporosis. Asian J Chem 18: 1091-1096, 2006.
4. Basu S, Michaelsson K, Olofsson H, Johansson S and Melhus H: Association between oxidative stress and bone mineral density. Biochem Biophys Res Commun 288: 275-279, 2001.

5. Forrest CM, Mackay GM, Oxford L, et al: Kynurenine pathway metabolism in patients with osteoporosis after 2 years of drug treatment. Clin Exp Pharmacol Physiol 33: 1078-1087, 2006.

6. Maggio D, Barabani, M, Pierandrei M, et al: Marked decrease in plasma antioxidants in aged osteoporotic women: results of a cross-sectional study. J Clin Endocrinol Metab 88: 1523-1527, 2003.

7. Dreher I, Schutze N, Baur A, et al: Selenoproteins are expressed in fetal human osteoblast-like cells. Biochem Biophys Res Commun 245: 101-107, 1998.

8. Yang S, Madyastha P, Bingel S, et al: A new superoxidegenerating oxidase in murine osteoclasts. J Biol Chem 276: $5452-5458,2001$

9. Muthusami S, Ramachandran I, Muthusamy B, et al: Ovariectomy induces oxidative stress and impairs bone antioxidant system in adult rats. Clin Chim Acta 360: 81-86, 2005.

10. Mlakar SJ, Osredkar J, Prezelj J and Marc J: The antioxidant enzyme GPX1 gene polymorphisms are associated with low BMD and increased bone turnover markers. Dis Markers 29: 71-80, 2010

11. Serin-Kilicoglu S and Erdemli E: New addition to the statin's effect. J Trauma 63: 187-191, 2007.

12. Uzzan B, Cohen R, Nicolas P, et al: Effects of statins on bone mineral density: a meta-analysis of clinical studies. Bone 40: 1581-1587, 2007.

13. Mundy G, Garrett R, Harris S, et al: Stimulation of bone formation in vitro and in rodents by statins. Science 286 1946-1949, 1999.

14. Montagnani A, Gonnelli S, Cepollaro C, et al: Effect of simvastatin treatment on bone mineral density and bone turnover in hypercholesterolemic postmenopausal women: A 1-year longitudinal study. Bone 32: 427-433, 2003

15. Bauer DC, Mundy GR, Jamal SA, et al: Use of statins and fracture: results of 4 prospective studies and cumulative metaanalysis of observational studies and controlled trials. Arch Intern Med 164: 146-152, 2004.

16. Rejnmark L, Buus NH, Vestergaard P, et al: Effects of simvastatin on bone turnover and bmd: A 1-year randomized controlled trial in postmenopausal osteopenic women. J Bone Miner Res 19: 737-744, 2004

17. Van Staa TP, Wegman S, de Vries F, Leufkens B and Cooper C: Use of statins and risk of fractures. JAMA 285: 1850-1855, 2001

18. Pasco JA, Kotowicz MA, Henry MJ, et al: Statin use, bone mineral density, and fracture risk: Geelong osteoporosis study. Arch Intern Med 162: 537-540, 2002.

19. Skoglund B, Forslund C and Aspenberg P: Simvastatin improves fracture healing in mice. J Bone Miner Res 17: 2004-2008, 2002.

20. Banai K, Brady K and McDonld F: A preliminary optical and electron microscopic study of the $\beta(1)$ integrin distribution pattern of human osteosarcoma-derived cells. Histochem Cell Biol 122: 75-80, 2004.

21. Chaplet M, Detry C, Deroanne C, et al: Zoledronic acid up-regulates bone sialoprotein expression in osteoblastic cells through Rho GTPase inhibition. Biochem J 384: 591-598, 2004.

22. Basu S, Michaelsson K, OIofsson H, et al: Association between oxidative stress and bone mineral density. Biochem Biophys Res Commun 288: 275-279, 2001.

23. Fraser JH, Helfrich MH, Wallace HM and Ralston SH: Hydrogen peroxide, but not superoxide, stimulates hone resorption in mouse calvariae. Bone 19: 223-226, 1996.

24. Mody N, Parhami F, Saraflian TA and Demer LL: Oxidative stress modulates osteoblastic differentiation of vascular and bone cells. Free Radic Biol Med 31: 509-519, 2001.

25. Ghosh-Choudhury N, Mandal CC and Choudhury GG: Statininduced Ras activation intergrates the phosphatidylinositol 3-kinase signal to Akt and MAPK for bone morphogenetic protein-2 expression in osteoblast differentiation. J Biol Chem 282: 4983-4993, 2007.

26. Yamashita M, Otsuka F, Mukai T, et al: Simvastatin antagonizes tumor necrosis factor-alpha inhibition of bone morphogenetic proteins-2-induced osteoblast differentiation by regulating Smad signaling and Ras/Rho-mitogen-activated protein kinase pathway. J Endocrinol 196: 601-613, 2008.

27. Maeda T, Matsunuma A, Kurahashi I, et al: Induction of osteoblast differentiation indices by statins in MC3T-E1 cells. J Cell Biochem 92: 458-471, 2004. 
28. Inoue I, Goto S, Mizotani K, Awata $\mathrm{T}$, et al: Lipophilic HMG-CoA reductase inhibitor has an anti-inflammatory effect: Reduction of MRNA levels for interleukin-1 $\beta$, interleukin-6, cyclooxygenase-2 and p22phox by regulation of peroxisome proliferator-activated receptor $\alpha$ (PPAR $\alpha)$ in primary endothelial cells. Life Sci 67: 863-876,2000.

29. Thunyakitpisal PD and Chaisuparat R: Simvastatin, an HMG-CoA reductase inhibitor, reduced the expression of matrix metalloproteinase-9 (Gelatinase B) in osteoblastic cells and HT1080 fibrosarcoma cells. J Pharmacol Sci 94: 403-409, 2004.

30. Maeda T, Kawane T and Horiuchi N: Statins augment vascular endothelial growth factor expression in osteoblastic cells via inhibition of protein prenylation. Endocrinology 144: 683-692, 2003.

31. Garrett IR, Gutierrez G, Chen D, et al: Statins stimulate bone formation by enhancing eNOS expression. J Bone Miner Res 16: S75, 2001b.

32. Song C, Guo Z, Ma Q, et al: Simvastatin induces osteoblastic differentiation and inhibits adipocytic differentiation in mouse bone marrow stromal cells. Biochem Biophys Res Commun 308: 458-462, 2003.
33. Pacova $\mathrm{H}$, Astl $\mathrm{J}$ and Martinek $\mathrm{J}$ : The pathogenesis of chronic inflammation and malignant transformation in the human upper airways: the role of $\beta$-defensins, eNOS, cell proliferation and apoptosis. Histol Histopathol 24: 815-820, 2009.

34. Desagher S and Martinou JC: Mitochondria as the central control point of apoptosis. Trends Cell Biol 10: 369-377, 2000.

35. Ashkenazi A and Dixit VM: Death receptors: Signaling and modulation. Science 281: 1305-1308, 1998.

36. Nakamura K, Bossy-Wetzel E, Burns K, et al: Changes in endoplasmic reticulum luminal environment affect cell sensitivity to apoptosis. J Cell Biol 150 : 731-740, 2000.

37. Li P, Nijhawan D, Budihardjo I, et al: Cytochrome c and dATPdependent formation of Apaf-1/caspase-9 complex initiates an apoptotic protease cascade. Cell 91: 479-489, 1997.

38. Rupinder SK, Gurpreet AK and Manjeet S: Cell suicide and caspases. Vascul Pharmacol 46:383-393, 2007.

39. Reed JC: Double identity for proteins of the Bcl-2 family. Nature 387: 773-776, 1997. 